\section{Imponerende om moderne familieterapi}

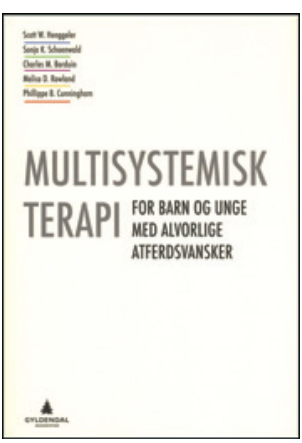

Scott W. Henggeler, Sonja K. Schoenwald,

Charles M. Borduin et al.

Multisystemisk terapi

For barn og unge med alvorlige

atferdsvansker. 311 s, tab, ill. Oslo: Gyldendal

Akademisk, 2013. Pris NOK 429

ISBN 978-82-05-42765-5
Denne læreboken henvender seg til fagfolk som jobber innenfor barnevernet og psykisk helsevern, primært til dem som er direkte involvert i multisystemisk terapi (MST). En gruppe på fem amerikanske professorer i psykiatri og atferdsvitenskap har sammen skapt et nyttig arbeidsredskap.

Multisystemisk terapi er et familiebasert behandlingstilbud hvor ungdommen bor hjemme, og familien får opplæring, veiledning og annen hjelp og støtte der de bor. Terapiformen er et alternativ til institusjonsbehandling og skal være prøvd før eventuell institusjonsplassering i barnevernet.

Boken er pedagogisk oppbygd og begynner med endringsteorien og det kliniske fundamentet og prosessene. Så følger adskilte kapitler hvor man beskriver intervensjoner i familien, i vennekretsen, i skole og på jobb, individuelt og i familiens støtteapparat. Avslutningsvis er det en forskningsoversikt og metoder for kvalitetssikring og forbedring av multisystemisk terapi. Grafiske figurer og tabeller blir hyppig brukt, i tillegg til kasuistikker og eksempler på utfylte behandlingsdokumenter.

Det kan være ganske overveldende å jobbe intensivt med en familie og en ungdom med alvorlige atferdsvansker som vold, kriminalitet og rusmisbruk. En terapeut skal aldri føle seg alene, og et team skal aldri gi opp en ungdom. En multisystemisk terapiterapeut er derfor en del av et multisystemisk terapiteam som har en multisystemisk terapiveileder tilknyttet teamet, i tillegg til en svært erfaren mulitsystemisk terapikonsulent som henter støtte fra den administrative ledelsen.

Den henviste atferden analyseres nøye for å forstå drivkreftene bak atferden. Deretter lages felles mål og visjoner for teamet og familien, og konkrete, presise mål defineres. Systemiske styrker og behov kartlegges. Det legges vekt på å skape engasjement og behandlingsallianse med både ungdommen, familien og nettverket. Gjennom behandlingsperioden er den samme terapeuten tilgjengelig 24 timer i døgnet. Venner, naboer og slektninger inkluderes for å hjelpe familien til å opprettholde prososial atferd hos ungdommen.

Det er imponerende hvordan forfatterne klarer å integrere atferdens biologiske grunnlag med utnytting av familiens sterke sider.

Dette er en meget grundig innføring i både multisystemisk terapi og teori og bør derfor være obligatorisk lesing for alle familieterapistudenter.

Alle fagpersoner som møter barn og ungdommer med alvorlige atferdsvansker, vil ha stor nytte av lese denne boken. Jeg anbefaler den også for alle leger som jobber i barne- og ungdomspsykiatrien.

Melanie Ekholdt Huynh

Konstituert overlege, BUP Grorud

Akershus universitetssykehus

\section{God innføring i klinisk revmatologi}

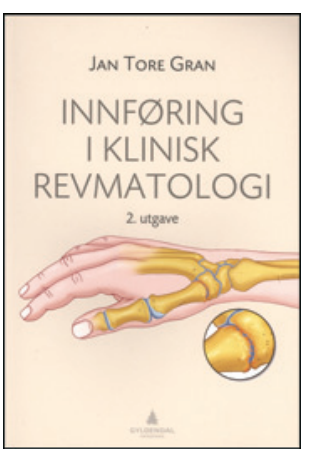

\author{
Jan Tore Gran \\ Innføring i klinisk revmatologi \\ 2. utg. 288 s, tab, ill. Oslo: Gyldendal \\ Akademisk, 2013. Pris NOK 495 \\ ISBN 978-82-05-45704-1
}

Tittelen - Innføring $i$ klinisk revmatologi - er etter min mening meget dekkende for innholdet $\mathrm{i}$ denne utgivelsen.

I forordet oppgis målgruppen som allmennleger, der boken skal utgjøre en hjelp til deres daglige arbeid med pasienter med revmatiske sykdommer. Andre som er angitt å kunne ha nytte av den, er sykepleiere/studenter, fysioterapeuter og medisinstudenter/leger. Mitt generelle inntrykk er at den utgjør en overkommelig og nyttig innføring for disse gruppene.

Boken er først og fremst en gjennomgang av klinisk arbeid, altså symptomer, funn, utredning, diagnose og behandling og som sådan egentlig godt egnet til undervisning av medisinstudenter. Forutsetningen er at de i tillegg også får bakgrunnsstoff som patologi, (auto-) immunologi og epidemiologi.

Første del utgjøres av generell innledning, laboratoriediagnostikk og utredning. Deretter omtales de enkelte sykdommene, differensialdiagnostikk og medikamenter ved revmatiske sykdommer. Siste del er en oversikt over klassifikasjonskriter eller diagnostiske kriterier for en del av sykdommene, i tillegg til et nyttig, relativt kortfattet stikkordregister.

Kapitlet om medikamenter er på over 30 sider og litt vanskelig å finne frem i, siden innholdsfortegnelsen er begrenset til to punkter. Medikamentene er ordnet alfabetisk etter generisk navn, men man må bla seg gjennom sidene eller bruke stikkordregisteret for å finne frem til de enkelte virkestoffene.

Når det gjelder omtalen av spondylartrittsykdommene, savner jeg definisjon og gjennomgang av såkalt non-radiografisk aksial spondylartritt, selv om det kan sies å være nevnt under klassifikasjonskriteriene.

Jeg synes kapitlet om utredning og diagnostikk av revmatiske sykdommer er spesielt bra, særlig med tanke på fornuftig arbeidsdeling mellom primær- og spesialisthelsetjeneste og sunn klinisk tenkning i forhold til symptomer, funn og utredning. Generelt virker boken vel gjennomarbeidet.

Jeg er litt forundret over at certolizumab sies å ha et annet angrepspunkt enn tumornekrosefaktor-alfa (TNF-alfa) (s. 57), og at det er vanlig å kontrollere RA-pasienter med røntgen eller MR av nakken hvert 1-2 år (s. 58). Dette siste ville jeg tro var avhengig av en individuell risikovurdering hos den enkelte pasient.

Andre utgave er rikere illustrert enn første utgave, og illustrasjonene virker gode og nyttige. Jeg kan trygt anbefale Innføring i klinisk revmatologi til de nevnte målgruppene.

Johan G. Brun

Overlege, Revmatologisk avdeling

Haukeland universitetssykehus 